\title{
Growth, regeneration and predation in three species of large coral reef sponges
}

\author{
Wilfried F. Hoppe \\ Carmabi Institute, PO Box 2090, Curaçao, Netherlands Antilles*
}

\begin{abstract}
To understand differences in survival strategies in 3 large Caribbean sponges, Neofibularia nolitangere, Ircinia strobilina and Agelas clathrodes, growth rates, regeneration efficiencies and aspects of predation were studied. All 3 species showed irregular and unpredictable growth in situ with wide variations in growth rate (including temporal shrinkages) within and among species. I. strobilina, but not the other species, grew more rapidly in the vertical than the horizontal direction. I. strobilina was the slowest growing, while $N$. nolitangere showed the highest growth rate and volume increase. Larger individuals of $I$. strobilina and $A$. clathrodes increased more slowly in volume than smaller ones; such a relation was not found for $N$. nolitangere. Linear growth rates of 0.7 to $2.4{\mathrm{~cm} \mathrm{yr}^{-1}}^{-1}$ for these sponges are similar to rates reported for other sessile reef organisms such as gorgonians and scleractinian corals. All 3 species regenerated all lesions efficiently. There was spatial differentiation in regeneration rates: top lesions in $N$. nolitangere and lateral lesions in $I$. strobilina regenerated faster than other lesions. Initial closure of the lesion by scar tissue was completed within $1 \mathrm{wk}$ in $I$ strobilina, but $N$. nolitangere was the first to show total regeneration (minimum of $5 \mathrm{wk}$ ). A. clathrodes showed the slowest and most uniform regeneration rate. Predation by Pomacanthinae (angelfishes) occurred only on $N$. nolitangere. Force-feeding pieces of 1 . strobilina appeared to cause paralysis and narcosis; forcefed $A$. clathrodes appeared to irritate the feeding tracts of the fishes. By their remarkable regeneration capacity and effective anti-predatory mechanisms these sponges appear to be well adapted to the dynamic reef environment.
\end{abstract}

\section{INTRODUCTION}

After settlement, sessile organisms are exposed to a large set of physical and biological processes endangering their survival. They reduce these dangers to varying extents by morphological (shape, structural enforcements), physiological (growth, regeneration, toxicity) and ecological (competition) defences. Growth rates, body shapes and dimensions have been recognized as ecologically important for sessile organisms in competition for space (Connell 1973, Jackson 1979). Similarly, the capacity to regenerate can reduce an organism's susceptibility to the effects of injuries from partial predation and physical disturbance. Although rapid regeneration heightens the survival potential of an organism, it possibly represents a heavy drain on the total energy budget (Bak 1983, Wahle 1983). Thus, the incidence and rate at which injuries are healed form

\footnotetext{
- Present address: Netherlands Institute for Sea Research (NIOZ), PO Box 59, 1790 AB, Den Burg (Texel), The Netherlands
}

part of the ecological fitness, especially for organisms living in highly dynamic environments such as coral reefs (Bak et al. 1977, Jackson \& Palumbi 1979, Bak \& Luckhurst 1980)

A limited number of studies on the ecological significance of predation, growth and regeneration in Porifera have been carried out on sponge species in the Antarctic (Dayton et al. 1974), temperate regions (Ayling 1981, 1983, Fell \& Lewandrowski 1981) and the tropics (Storr 1964, 1976, Reiswig 1973, Jackson \& Palumbi 1979). The majority of the data concern cryptic and encrusting sponge species and relatively little is known about the larger and massive species (Storr 1964, Reiswig 1973). These large sponges attain dimensions comparable to dominant sessile organisms on reefs, such as gorgonians and scleractinian corals. They also play a potentially similar role in the occupation of space on reef bottoms. This raises the question of degree of ecological similarity among these different groups of organisms.

Apart from aspects of spatial competition, predation constitutes a major potential threat to survival. Gas- 
tropods (Dayton et al. 1974), polychaetes (Fauchald \& Jumars 1979, Pawlik 1983), asteroids (Dayton et al. 1974), echinoids (Ayling 1981) and fish (Bakus 1964, 1966, Randall \& Hartman 1968, Ayling 1981) have been reported to prey on sponges. On coral reefs, fish predation is the most serious cause of disruption of physical integrity in large, exposed sponges (Randall \& Hartman 1968, Reiswig 1973, pers. obs.). The widespread incidence of toxicity in tropical sponge species has been attributed to this specific predation pressure by coral reef fishes (Bakus 1964, Bakus \& Green 1974, Green 1977).

In this paper I present data on growth rate, regeneration efficiency and predation by fish in the sponge species Neofibularia nolitangere (Duchassaing \& Michelotti, 1864) (hereafter $N$. nolitangere), Ircinia strobilina (Lamarck, 1814) (hereafter I. strobilina) and Agelas clathrodes (Schmidt, 1870) (hereafter A. clathrodes). Only predation by fish has been considered in the present study, for no other group of organism, including symbionts living inside the 3 species discussed in this paper was found to endanger the physical integrity of the sponges (Hoppe et al. unpubl.). Data are discussed in terms of differences between the sponge species and of strategies employed by large sessile organisms on coral reefs

\section{MATERIALS AND METHODS}

Experiments and observations on growth, regeneration process and predation were carried out on the coral reefs of Curaçao, Netherlands Antilles.

Growth. Ten individuals (individuals defined sensu Bergquist 1978) of each of the 3 species were selected. For each individual initial dimensions were measured and its position marked at a reef site near the Carmabi Institute (Carmabi Buoy 2, see Fig. 1; for description see Bak 1977). Depths ranged from 6 to $22 \mathrm{~m}$ for. $N$. nolitangere, from 12 to $27 \mathrm{~m}$ for $I$. strobilina and from 22 to $35 \mathrm{~m}$ for $A$. clathrodes, corresponding with the natural ranges of these species over the Curaçao reef profile (pers. obs.). To detect possible seasonal variations in growth rate, measurements were taken at 3 mo intervals (January, April, July, October) over a 2 yr period (1984 to 1985).

Growth was measured accurately by placing a permanent rectangular PVC frame around each sponge individual, perpendicular to the reef substratum. This frame cut an imaginary 2-dimensional plane through the body, which allowed measurements of linear growth in horizontal and vertical directions relative to the frame and the substratum. Each measurement consisted of determining the distance between various locations at the sponge body wall and the frame

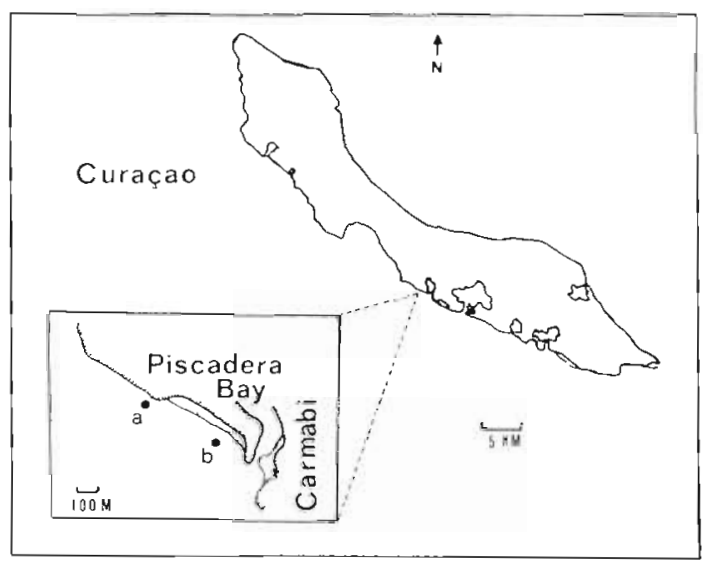

Fig. 1. Curaçao, showing locations where periodic measurements of sponge growth ( $\mathrm{a}_{\text {; }}$ Buoy 2 ) and sponge regeneration experiments ( $b$; Buoy 0 ) were carried out

(as the fixed reference point) using a measuring-rod with a millimetre scale. The repeatability and the correct 3-dimensional orientation of the measurements was guaranteed by passing the round measuring-rod through closely fitting pipes glued to the supporting frame. Each measurement was made 3 times (methodical error $<1 \mathrm{~mm}$ ). The growth vector at a particular location on the sponge body wall was assumed to be perpendicular to the body wall. The measurements were corrected for any deviation from the $90^{\circ}$ angle of contact between the sponge and measuring-rod.

Bodies of the dictyoceratid species $I$. strobilina are occasionally contracted. Only measurements of individuals in their relaxed state were used in this study.

Regeneration. Regeneration capacity of the sponges was studied in situ on a reef site near the Carmabi Institute (Buoy 0, Fig. 1). For this, 27 individuals of A. clathrodes (depths ranged from 16 to $33 \mathrm{~m}$ ), 39 individuals of $I$. strobilina ( 6 to $28 \mathrm{~m}$ ) and 36 individuals of $N$. nolitangere $(6$ to $24 \mathrm{~m}$ ) were used. Experimental lesions were cut into the body wall using a sharp dissecting knife and a rectangular mould. Lesions were of 2 sizes: 1 by $1 \mathrm{~cm}^{2}$ and 3 by $3 \mathrm{~cm}^{2}$, each $1 \mathrm{~cm}$ deep. Only one lesion was made in each sponge, either at the side or on the top of the body wall. Thus regeneration could be observed in relation to lesion size in different locations on the sponges. The experiment was started in January 1984. Regeneration was initially followed every day and then, after effective closure of the ectosome (by a scar), every 2 to $3 \mathrm{~d}$.

Predation. Whole sponges and pieces of each sponge species were presented in aquaria to fishes of the subfamily Pomacanthinae (angelfishes), a main group which feeds predominantly on sponge material (Randall \& Hartman 1968). Three species, Pomacanthus paru (Bloch, 1787) (French angel), Holacanthus ciliaris 
(Linnaeus, 1758) (queen angel) and Holacanthus tricolor (Bloch, 1795) (rock beauty), were used in these experiments. They are the most common species of this group on the Curaçao coral reef. After capture on the reef, with a net and a solution of the sedating agent quinaldine, the fishes were placed in aquaria which already contained the intact sponges. After $24 \mathrm{~h}$ of acclimatization in their new environment, nibbling and intentional feeding activities were visually monitored over the next $3 \mathrm{~d}$. In a similar experiment, pieces of each sponge species were presented to the 3 fish species. Recognition of food and feeding activity were observed over the next few hours. In both experiments the non-toxic and readily eaten sponge (Green 1977) Callyspongia vaginalis (Lamarck, 1814) was presented as a reference.

As a follow-up to the aquarium experiments, pieces of A. clathrodes and I. strobilina were force-fed to the fishes. For this experiment the most abundant species, Holacanthus tricolor, was chosen. To allow for observations under near-natural conditions, captured fishes were kept in situ underwater in large cages (Curaçao fish traps: 'canastas'). Each cage $(n=3)$ contained 2 fish. Two separate force-feeding experiments were carried out presenting single and double quantities of sponge material. In all experiments 2 fish were fed pieces of Callyspongiae vaginalis as a reference. Force-feeding consisted of holding the fish and pushing a ca $25 \mathrm{~mm}^{3}$ piece of freshlycut sponge tissue into the fish's stomach. Reactions and movements of the fishes were observed for $1 \mathrm{~h}$ after they were force-fed and again the next day.
Additional information on predation was gathered by incidental field observations over a total period of $3 \mathrm{yr}$ of field work.

\section{RESULTS}

\section{Growth}

The periodic measurements showed growth to be an irregular and unpredictable phenomenon in all 3 sponge species. A wide variation in growth rate was found for subsequent measurements of individual points on the sponge body wall. A similar variation was found in the comparison of parallel measurements along the whole body contour of an individual sponge. Zero growth rates and even negative values (shrinkage) were found at intervals for some points on individuals of all 3 species. There was no apparent pattern in this variation, but overall size of the sponges did increase.

Mean horizontal and vertical linear growth rates for each of the species are shown in Table 1. As with the measurements per individual sponge, linear growth rates per species showed a wide variation. In I. strobilina grow th was significantly and positively correlated with depth $(r=0.91, p<0.01)$. In making comparisons between the growth rates one has to consider the wide variation in growth data, which is apparently inherent to the growth process in these sponges.

Vertical growth, i.e. away from the substratum, was significantly greater than horizontal growth only in $I$. strobilina (Table 1). No difference was found between

Table 1. Neofibularia nolitangere, Ircinia strobilina and Agelas clathrodes. Average linear growth rates

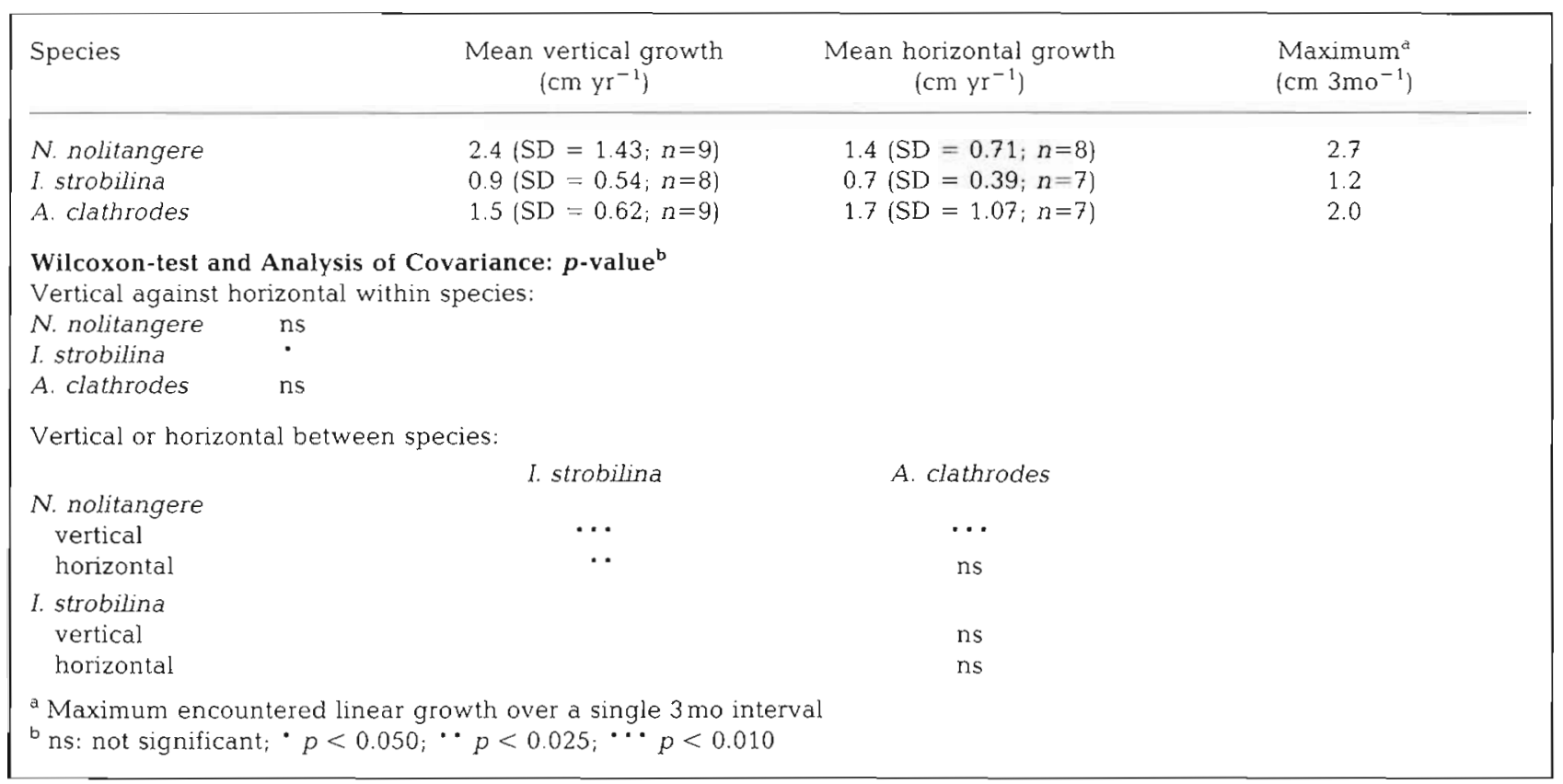


the 2 growth components in $A$. clathrodes and in N. nolitangere. I. strobilina grew most slowly in both directions; $N$. nolitangere grew fastest. The same difference in growth capacity between the species is clearly expressed in their maximum growth rates (Table 1 ).

Knowing the linear growth rates, the increase in volume can be estimated from models of the generalized shape of each of the 3 species. A typical individual of $N$. nolitangere has the shape of a vase (Fig. 2A), with a large central cavity, and the sponge volume may be modelled as a thick-walled cylinder. A typical $I$ strobilina has the shape of an elongated cushion (Fig. 2B), the volume of which can best be approximated by a solid cylinder with an ellipsoid profile. A. clathrodes has a characteristic flabelliform shape with a.convex irregular ostial side and a smooth straight or slightly concave oscular side (Fig. 2C). The shape of this complex body can be approximated, and its volume calculated, by taking the top quarter part of a spheroid after cutting this twice in half along 2 perpendicular planes. A spheroid is created by the rotation of the area of an ellipse around its minor axis.
An average increase in volume was estimated for the 3 species by calculating the volume of each sponge individual at the start and end of the 2 yr measuring period, using initial dimensions and both horizontal and vertical growth rates. $N$. nolitangere increased its volume significantly faster than $A$. clathrodes and I. strobilina (respectively $p<0.01$ and $p<0.10$; Wilcoxon 2-sample test; Table 2), which were similar.

Increases in volume of all 3 species were very variable. At least some of this variability was due to decreased rates of growth with increasing size in $I$. strobilina and $A$. clathrodes (Spearman's rank correlation between initial volume and percent volume increase over 2 yr was $r=$ $-0.75, \mathrm{df}=5$, and $r=-0.72, \mathrm{df}=5$ respectively; both $p<0.05)$. No significant correlation was found for $N$. nolitangere $(r=-0.333, \mathrm{df}=6 ; p>0.10)$.

\section{Regeneration}

In all individuals of all 3 species the experimental tissue lesions showed regeneration. Three separate
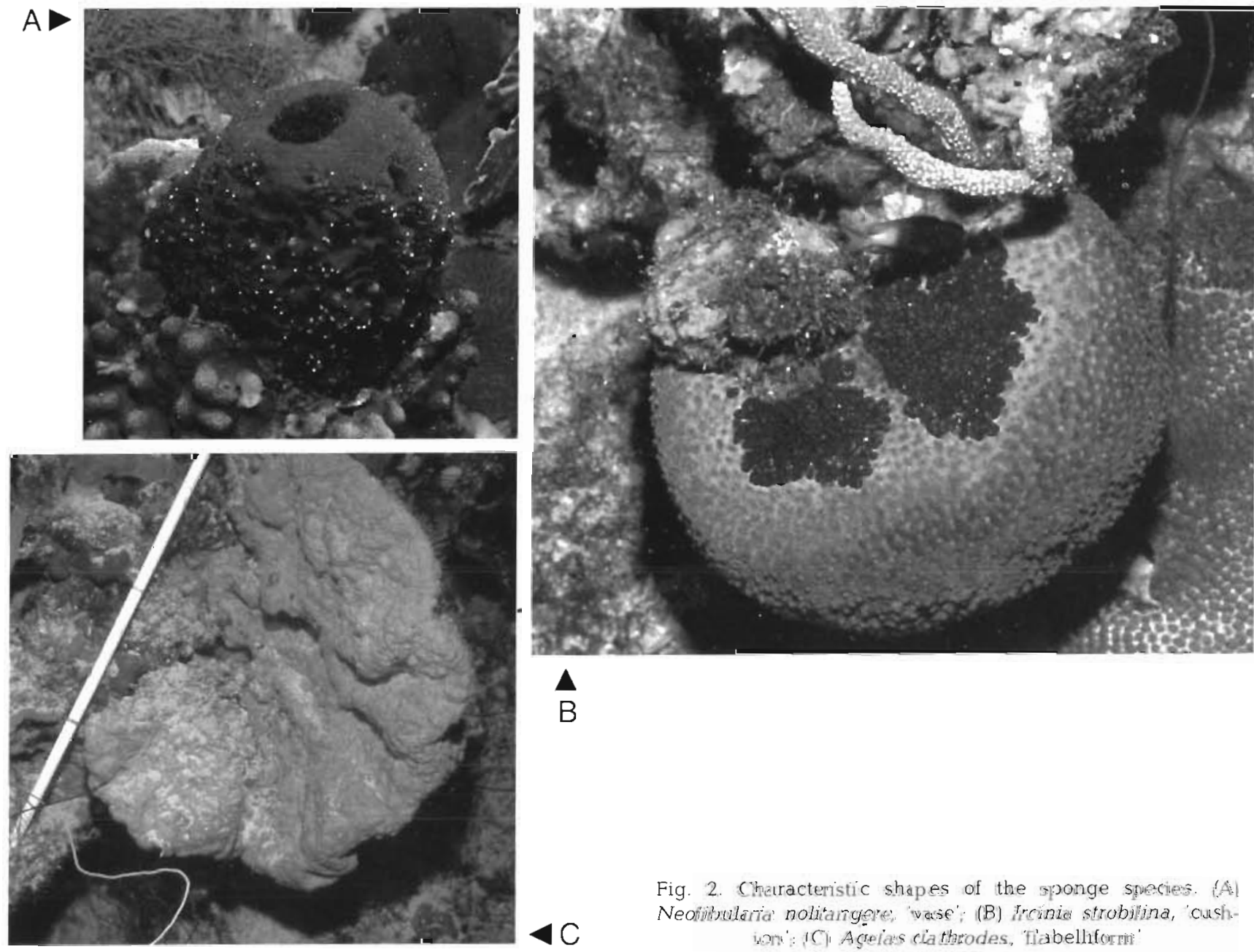

B

Fig. 2. Characteristic shapes of the sponge species. (A) Neofibularia nolitangere, 'vase'; (B) Ircinia strobilina, 'cushion: $1 \mathrm{Cl}$ Agelas clathrodes, 'flabelliform' 
Table 2. Neofibularia nolitangere, Ircinia strobilina and Agelas clathrodes. Increase in volume

\begin{tabular}{|lrr}
\hline Species & $\begin{array}{c}\text { Volume increase } \\
\text { per year }(\%)\end{array}$ & $\begin{array}{c}\text { Time to double } \\
\text { volume }\end{array}$ \\
\hline N. nolitangere & $19.4(\mathrm{SD}=11.3 ; n=8)$ & $5.4(\mathrm{SD}=3.3 ; n=8)$ \\
I. strobilina & $10.6(\mathrm{SD}=8.5 ; n=7)$ & $9.9(\mathrm{SD}=5.3 ; n=7)$ \\
A. clathrodes & $7.7(\mathrm{SD}=2.9 ; n=7)$ & $11.0(\mathrm{SD}=5.4 ; n=7)$ \\
& & \\
assuming constant rates of growth & \\
\hline
\end{tabular}

phases of regeneration could be distinguished. During Phase 1, the damaged surface of the lesion was closed by a characteristic scar tissue. This tissue differed in colour and texture from undamaged ectosome tissue. In Phase 2, the scar tissue changed back to the normal ectosome appearance, leaving only a depression in the surface of the sponge. The third and last phase of regeneration was the filling of the depression.

Regeneration of lesions in all 3 species followed the same sequence of events, but there were marked differences in timing of phases. In I. strobilina, the damaged bare outer surface of the choanosome and fibre bundle endings degenerated, giving the lesion a fluffy appearance. In a relatively short time this degenerated material was rejected and a characteristically dark-pigmented, smooth and leathery scar tissue remained, effectively closing the wound. This tissue changed slowly back to the normal grey colour and texture, simultaneously levelling out the depression of the original lesion.

Regeneration of $A$. clathrodes followed a comparable pattern of choanosome degeneration and rejection, but scar tissue was formed by a thin and easily damaged membrane of a lighter orange-red than the normal ectosome. Such fragility of the primary scar tissue in this sponge is apparently caused by the absence of enforcing spongin fibres and spicules normally present in the ectosome. Further regeneration consisted of the reinforcement and thickening of the overlying tissue, which recovered normal colour and texture. No filling of the lesion depression was detected in this species.

In $N$. nolitangere scar tissue was formed, after rejection of the damaged choanosome, by a coarse net of transparent fibres which left the white colour of the choanosome still visible. After a short time the tissue was invaded by a purplish-brown colour, which spread quickly over the whole surface of the lesion. This happened simultaneously with an increase in density of fibres. Any decrease in light level at the site of the lesion (i.e. by clogging of sediment or overgrowth by algae) retarded healing. By the time the normal colour was resumed, texture of the overlaying tissue could no longer be distinguished from the normal undamaged ectosome and the depression was subsequently quickly levelled.

Table 3 summarizes the Phase 1 (scar formation) regeneration times of lesions differing in size and location in the 3 sponge species. Differences in values within and between species were tested with a Wilcoxon 2-sample test (significance accepted at $p<0.05$ ).

In $N$. nolitangere the small $1 \mathrm{~cm}^{2}$ lesion at the top of the sponge regenerated most rapidly, significantly faster than other sized and located lesions. All other types of lesions on this sponge did not significantly differ from each other in rate of scar formation. Similarly, in I. strobilina the lateral $1 \mathrm{~cm}^{2}$ lesion closed the damaged surface by a scar significantly more rapidly than the other lesions. In $A$. clathrodes no significant differences were found in the scar formation rates of the various lesions.

In comparing species, for lesions corresponding in size and location, I. strobilina regenerated lesions in all instances significantly more rapidly to a scar (end of Phase 1) than did the other 2 species. Differences in scar formation rates between $N$. nolitangere and $A$. clathrodes were not significant, with the exception of the top $1 \mathrm{~cm}^{2}$ lesion, which regenerated significantly more quickly to a scar in $N$. nolitangere.

Approximate times required for total regeneration in the 3 sponge species, including Phases 2 and 3 follow-

Table 3. Neofibularia nolitangere, Ircinia strobilina and Agelas clathrodes. Mean period (d) of Phase 1 (scar formation, see text) in the regeneration process of $1 \mathrm{~cm}$ deep experimental lesions

\begin{tabular}{|c|c|c|c|c|}
\hline \multirow[t]{3}{*}{ Species } & \multicolumn{4}{|c|}{ Lesion size and location } \\
\hline & \multicolumn{2}{|c|}{$1 \times 1 \mathrm{~cm}^{2}$} & \multicolumn{2}{|c|}{$3 \times 3 \mathrm{~cm}^{2}$} \\
\hline & Top & Lateral & Top & Lateral \\
\hline $\begin{array}{l}\text { N. nolitangere } \\
(n=36)\end{array}$ & $13.5(\mathrm{SD}=3.4 ; n=12)$ & $22.2(\mathrm{SD}=9.3 ; n=7)$ & $22.0(\mathrm{SD}=4.1 ; n=9)$ & $32.6(\mathrm{SD}=14.3 ; n=8)$ \\
\hline $\begin{array}{l}\text { I. strobilina } \\
(n=39)\end{array}$ & $8.3(\mathrm{SD}=3.0 ; n=12)$ & $5.2(\mathrm{SD}=0.8 ; n=9)$ & $8.7(\mathrm{SD}=2.9 ; n=9)$ & $7.3(\mathrm{SD}=1.6 ; n=9)$ \\
\hline $\begin{array}{l}\text { A. clathrodes } \\
(n=27)\end{array}$ & $27.6(\mathrm{SD}=12.1 ; n=5)$ & $25.4(\mathrm{SD}=9.7 ; n=7)$ & $24.7(\mathrm{SD}=5.2 ; n=6)$ & $25.7(\mathrm{SD}=4.0 ; n=9)$ \\
\hline
\end{tabular}


Table 4. Neofibularia nolitangere, Ircinia strobilina and Agelas clathrodes. Phases (wk) of the total lesion regeneration process. Phase 1: closure of lesion by scar-tissue; Phase 2: recovery of tissue to normal appearance; Phase 3 : levelling of lesion depression

\begin{tabular}{lcccc}
\hline Species & Phase 1 & Phase 2 & Thase 3 \\
N. nolitangere & 2 & 1 & $2-17$ \\
I. strobilina & 1 & 3 & $>6$ & 0 \\
A. clathrodes & $3-4$ & 6 & $\infty$ & $\infty$ \\
\hline
\end{tabular}

ing scar formation, are given in Table 4. Although lesion surfaces in $I$. strobilina were most rapidly closed by a scar (Phase 1), lesions in $N$. nolitangere were the first to resume normal tissue colour and texture (end of Phase 2). $N$. nolitangere was also first in reaching total regeneration by filling of the depression (end of Phase 3). The wide range of weeks over which $N$. nolitangere reached completion of Phase 3 was caused by fouling problems with sediment and algae, which appeared specifically on the damaged and regenerating site of the lesion. A. clathrodes showed the lowest regeneration efficiency, with apparent absence of Phase 3.

\section{Fish predation}

In the aquaria, none of the 3 species of Pomacanthinae preyed on intact $N$. nolitangere, $I$. strobilina or A. clathrodes. The reference species Callyspongia vaginalis was readily eaten, all bites characteristically being taken at the same site on the sponge. Apparently a damaged surface incites fish to take further bites at the same location. In an experiment with fresh lesions on the surfaces of the 3 sponge species, it appeared that only $N$. nolitangere was preyed upon. Here the fishes similarly took bites only at the damaged location. The volumes of tissue eaten were quite limited, possibly due to the stress caused by the unnatural environment of the experimental aquaria.

The aquarium experiments were repeated with cut pieces of sponge. Again only $N$. nolitangere and the reference Callyspongia vaginalis were accepted as prey. The fishes frequently tested pieces of $I$. strobilina and $A$. clathrodes by nibbling, but these sponges were not eaten.

The rejected species, I. strobilina and A. clathrodes, were tested for a possible deterrent or toxic effect by force-feeding sponge pieces under field conditions to individuals of Holacanthus tricolor (rock beauties). After being force-fed, fishes invariably swam to the bottom, ventilating rapidly for several minutes to overcome stress of handling. After feeding the non-toxic control Callyspongia vaginalis, the fishes subsequently regained normal swimming behaviour. After feeding
I. strobilina, $H$. tricolor individuals started to show moderate paralysis over the total body at about $5 \mathrm{~min}$ after the actual force-feeding. The fishes clearly showed problems in keeping their balance - hanging tail-down or on their sides. The paralysis and drowsiness disappeared completely 20 to 30 min after its first signs. No detectable long-lasting effect was observed for the following $24 \mathrm{~h}$ and thereafter. Force-feeding of pieces of $A$. clathrodes caused spasmodic and convulsive movements of the fishes, unlike the effects of the other 2 sponge species. It mostly resulted in vomitting of the fed piece of sponge. In cases where the piece remained inside the stomach, no other effect than the apparent irritation was observed.

Feeding double quantities of both sponge materials caused the described effects to be more marked, with a longer-lasting and more severe drowsiness or irritation.

Additional observations in the field confirm that, of the 3 sponges, only $N$. nolitangere is preyed upon by pomacanthinid fishes. Predation marks and actual feeding activity by angelfishes on $N$. nolitangere were frequently observed. Angelfishes were observed to feed predominantly on the top part and the inside wall of the central cavity of $N$. nolitangere individuals. As was found for individual sponges in the aquarium experiment, the field observations confirmed that individuals showing signs of predation are more susceptible to repeated fish predation than are intact specimens.

\section{DISCUSSION}

The phenomenon of the remarkably irregular and unpredictable growth in Neofibularia nolitangere, Ircinia strobilina and Agelas clathrodes has been noticed in several other growth studies on a wide variety of sponge species (Reiswig 1973, Dayton 1979, Fell \& Lewandrowski 1981, Ayling 1983). Tissue shrinkage and fluctuations in growth rate may be a reaction to environmental. stress and have been connected with seasonal variation in water temperature and reproductive activity (Reiswig 1973, Elvin 1976). No such cues to temperature stress or to the patterns in reproductive activity of the 3 sponge species (Hoppe \& 
Reichert 1987, Hoppe 1988) have been observed in the present study

Mean linear growth rates in the 3 species studied were low and fell well within the range reported for other large reef organisms such as massive and platelike stony corals (Bak 1976, Gladfelter et al. 1978) and some gorgonian species (Grigg 1977). Linear growth rates are of great ecological interest because of their relevance to acquisition of substratum, to the seeking or avoidance of competition with nearby or overtopping neighbours, and to the advantages of becoming reasonably large, i.e. to survive partial burial. I. strobilina showed a tendency to grow more rapidly upward away from the substratum than to spread in the horizontal plane, which indicates a predominantly nonconfrontational strategy (Jackson 1979). In $A$. clathrodes and $N$. nolitangere no difference between vertical and lateral growth was found, which in the former species is reflected by its potential to grow into a regular symmetrical shape.

$N$. nolitangere showed the greatest increase in body volume, with almost $20 \% \mathrm{yr}^{-1}$. Such a value rates high to intermediate compared to other equally sized sponge species (Storr 1964, Reiswig 1973, Dayton 1979). Even after correction between the species for differences in tissue density and internal canal volume (Hoppe unpubl.), it appears that $N$. nolitangere increased its real tissue mass twice as fast as the other 2 species in this study. Massive mound-shaped organisms, like large sponges, show determinant growth due to physiological constraints (Storr 1964, Reiswig 1973, Jackson 1979). A reduction in percent volume growth with increasing size was observed for $I$. strobilina and A. clathrodes. No such relationship was found for $N$. nolitangere. In this species the dermal symbiont layer of cyanobacteria (Ruetzler pers. comm., own obs.) may be effective in stretching the physiological limits, at least in the size range measured here.

The 3 sponge species all showed high regenerative efficiency. Regeneration rates were comparable to rates in plexaurid gorgonians (Lang da Silveira \& van 't Hof 1977, Wahle 1983) and in a variety of encrusting reef organisms (Jackson \& Palumbi 1979, Bak et al. 1981, Palumbi \& Jackson 1982), but fast compared to regeneration in the overwhelming majority of scleractinian corals (Bak et al. 1977, Bak \& Stewart van Es 1980; but see Bak 1983). Storr (1976) found a 3 d regeneration period for undefined lesions in a sponge species, reported as $I$. strobilina, in the Gulf of Mexico. In contrast, in the present study $I$. strobilina needed ca $1 \mathrm{wk}$ to form the characteristic black scar and another $3 w k$ to recover normal appearance of the ectosome. With a minimum of $3 w k, N$. nolitangere was the most rapid of the 3 studied species in total ectosome recovery.
In modular and encrusting organisms the mode of regeneration differs from that described in this study for large massive sponges, but its ecological significance is the same. Fast regeneration precludes settlement and subsequent overgrowth by competing organisms or total disruption of the physiological integrity of the organism (Jackson \& Palumbi 1979, Bak 1983, Wahle 1983). The ectosome in sponges functions as a defensive outer layer to impair settlement of organisms on its surface (Sarà \& Vacelet 1973, Bergquist 1978). Settlement and growth of algae were observed to occur specifically at the exposed choanosome of the lesions, but this did not prevent complete regeneration. As a relatively shallow living species, $N$. nolitangere turned out to be more endangered to this kind of fouling by algal growth than the other 2 species, leading to the broad variation in total regeneration times. A. clathrodes is most vulnerable to the effects of injuries because of its initially weak scar tissue and the relatively slow regeneration rate.

Size and location of lesions were found to influence regeneration rates in $N$. nolitangere and $I$. strobilina. This effect, and its absence in A. clathrodes, shows parallels to the respective linear growth patterns. Apparently, specific parts of the sponge body differ in their physiological potential. Sponges are considered individuals when invested by a continuous pinacoderm and show a low and uniform internal organisation (Bergquist 1978). Despite this uniformity, this study shows a physical unevenness in growth and regeneration rate within individual sponges.

Although there may be some similarities between growth and regeneration, the more than 10-fold difference in rate between the 2 processes demonstrates that they are not the same. Regeneration in sponges is believed to occur by reorganization of cells rather than by actual growth (Korotkova 1963, Reiswig 1973, Jackson \& Palumbi 1979). The observed invasion of coloured material into the scar tissue of $N$. nolitangere supports this idea. The colour probably originates from cyanobacterial symbionts. These organisms enhance the regeneration process, because experimentally induced aposymbiontic $N$. nolitangere regenerated injuries much more slowly than normal individuals (Hoppe et al. unpubl.).

Considering the total data set gathered on growth and regeneration of the 3 sponge species, 2 additional conclusions can be made. Firstly, having the fastest rates of growth and regeneration, $N$. nolitangere seems to put the most energy into physical maintenance, relative to the other 2 species. Secondly, age determination of individuals of all 3 sponges will be virtually impossible. Maximum age in large and massive sponge species is said to vary between 30 and about $100 \mathrm{yr}$ (Storr 1964, Reiswig 1973). The observed irregularity in 
growth and the remarkable regenerative potential makes age determination difficult, as with age determination in some stony corals (Hughes \& Jackson 1980). Thus, given stable environmental conditions, large sponge individuals could be several hundreds of years old.

Predation by Pomacanthinae was observed only on $N$. nolitangere. $N$. nolitangere is known to be irritating and toxic to humans (Halstead 1965, pers, obs.) and has been found to be toxic to fish, though this was dependent on the test method used (Bakus \& Thun 1979). Toxicity per se does not prevent predation. Some fish may be less vulnerable to a specific toxic agent or are able to reduce the effect by feeding on limited quantities of a toxic species as part of a mixed sponge diet (Randall \& Hartman 1968). Also a dense spicule content does not necessarily prevent predation, as was found for several antarctic sponge species (Dayton et al. 1974) and in the present study for $N$. nolitangere. In contrast, the large spicules (acanthostyles) with verticillate spines, which are characteristic of the Agelasidae (Bergquist 1978) and present in A. clathrodes, may have caused irritation of fish feeding tracts in the forcefeeding experiment. Such a defence mechanism is more likely to be of mechanical than of chemical nature, for $A$. clathrodes has been reported to be nontoxic (Bakus \& Thun 1979). A chemical defence was found for I. strobilina, which has been reported as a toxic species (Green 1977). Force-fed Holacanthus tricolor showed temporarily paralysis and loss of balance. In contrast with observations by Green (1977) in a similar experiment however, the fishes regained normal swimming behaviour. A higher dose may prove to be lethal, because feeding larger quantities of I. strobilina caused more marked symptoms.

The discovery of such a means of defence in 2 out of the 3 large sponge species in this study is consistent with the idea that antipredatory mechanisms occur generally in exposed reef organisms (Bakus 1964, Cameron 1974). The ecological significance of such a mechanism seems evident, but still needs confirmation from field experiments with the potential predators, since the toxic species $N$. nolitangere was readily preyed on by fish. In a fish predation study on soft corals (La Barre et al. 1986) taste was found to be more important than olfaction in the recognition of unpalatability. A similar mechanism may be deterring predation in A. clathrodes and I. strobilina. Cut pieces of these sponge species were tried by nibbling without actually eating or damaging the material.

In conclusion, the 3 sponge species appeared to be slow-growing organisms with good prospects of survival on the reef. This is achieved by remarkable regenerative efficiencies and effective mechanisms to reduce the risks of predation.
Acknowledgements. The Carmabi Institute at Curaçao (Netherlands Antilles) provided research facilities. The help of staff and diving assistants, especially the indispensable help of Franklin Isabella with the fish force-feeding experiments, is gratefully acknowledged. Dr R. P. M. Bak, Dr R. W. M. van Soest, Prof. Dr J. H. Stock and 3 anonymous reviewers critically read the manuscript and made valuable suggestions. This study was supported by a grant from the Netherlands Foundation for Advancement of Tropical Research (WOTRO) W84-216.

\section{LITERATURE CITED}

Ayling, A. L. (1981). The role of biological disturbance in temperate subtidal encrusting communities. Ecology 62: $830-847$

Ayling, A. L. (1983). Growth and regeneration rates in thinly encrusting Demospongiae from temperate waters. Biol. Bull. mar biol. Lab., Woods E fole 165: 343-352

Bak, R. P. M. (1976). The growth of coral colonies and the importance of crustose coralline algae and burrowing sponges in relation with carbonate accumulation. Neth. J. Sea Res. 10: 285-337

Bak, R. P. M. (1977). Coral reefs and their zonation in the Netherlands Antilles. Am. Ass. Petrol. Geol. USA Stud. Geol. 4: 3-16

Bak, R. P. M. (1983). Neoplasia, regeneration and growth in the reef-building coral Acropora palmata. Mar. Biol. 77: 221-227

Bak, R. P. M., Brouns, J. J. W. M., Heys, F. M. L. (1977). Regeneration and aspects of spatial competition in the scleractinian corals Agaricia agaricites and Montastrea annularis. Proc. Third Int. Coral Reef. Symp., Miami 1. 143-148

Bak, R. P. M., Luckhurst, B. E. (1980). Constancy and change in coral reef habitatas along depth gradients at Curaçao. Oecologiá (Berl.) 47: 145-155

Bak, R. P. M., Steward-van Es, Y (1980). Regeneration of superficial damage in the scleractinian corals Agaricia agaricites and Porites astreoides. Bull. mar Sci. 30: 883-887

Bak, R. P. M., Sybesma, J., van Duyl, F. C. (1981). The ecology of the tropical compound ascidian Trididemnum solidum. II. A.bundance, growth and survival. Mar. Ecol. Prog. Ser 6: $43-52$

Bakus, G. J. (1964). The effects of fish-grazing on invertebrates evolution in shallow tropical waters. Allan Hancock Found. Publ. 27: p. 29.

Bakus, G. J. (1966). Some relationships of fishes to benthic organisms on coral reets. Nature, Lond. 210: 280-284

Bakus, G. J., Green, G. (1974). Toxicity in sponges and Holothurians: a geographic pattem. Science 185: 951-953

Bakus, G. J., Thun, M. A. \{1979\}. Bioassays on the toxicity of caribbean sponges. In: Lévi, C., Boury-Esnault, N. (eds.) Biologie des spongiaires, Vol. 291. Coll. Int. du C.N.R.S., Paris, p. $417-422$

Bergquist, P. R. (1978). Sponges. Univ. California Press, Los Angeles, p. 268

Cameron, A. M. (1974). Toxicity phenomena in coral reef waters. Proc. Second Int. Coral Reef Symp., Brisbane 1: $513-518$

Connell, J. H. (1973). Population ecology of reef-building corals. In: Jones, O. A., Endean, R. (eds.) Biology and geology of coral reefs, Vol 2. Academic Press, New York, p. $205-245$ 
Dayton, P. K. (1979). Observations on growth, dispersal and population dynamics of some sponges in McMurdo Sound, Antarctica. In: Lévi, C., Boury-Esnault, N. (eds.) Biologie des Spongiaires, Vol. 291. Coll. Int. du C.N.R.S., Paris, p. 271-282

Dayton, P. K., Robilliard, G. A., Paine, R. T., Dayton, L. B. (1974). Biological accommodation in the benthic community at McMurdo Sound, Antarctica. Ecol. Monogr. 44 $105-128$

Elvin, D. W (1976). Seasonal growth and reproduction of an intertidal sponge, Haliclona permollis (Bowerbank). Biol. Bull. mar. biol. Lab., Woods Hole 151: 108-125

Fauchald, K., Jumars, P. A. (1979). The diet of worms: a study of polychaete feeding guilds. Oceanogr. mar. Biol. A. Rev. 17: 193-282

Fell, P. E., Lewandrowski, K. B. (1981). Population dynamics of the estuarine sponge, Halichondria sp., within a New England eelgrass community. J. exp. mar. Biol. Ecol. 55: $49-63$

Gladfelter, E. H., Monahan, R. K., Gladfelter, W. B. (1978) Growth rates of five reef-building corals in the northeastern caribbean. Bull. mar. Sci. 28: 728-734

Green, G. (1977). Ecology of toxicity in marine sponges, Mar. Biol. 40: 207-215

Grigg, R. W. (1977). Population dynamics of two Gorgonian corals. Ecology 58: 278-290

Halstead, B. W. (1965). Poisonous and venomous marine animals of the world, Vol. 1. Invertebrates. U.S. Government Printing Office, Washington D.C., p. 994

Hoppe, W. F. (1988). Reproductive patterns in three species of large coral reef sponges. Coral Reefs 7: 45-50

Hoppe, W F., Reichert, M. J. M. (1987). Predictable annual mass release of gametes by the coral reef sponge Neofibularia nolitangere (Porifera: Demospongiae). Mar. Biol. 94: 277-286

Hughes, T P., Jackson, J. B. C. (1980). Do corals lie about their age? Some demographic consequences of partial mortality, fission, and fusion. Science 219:713-715

Jackson, J. B. C. (1979). Morphological strategies of sessile animals. In: Larwood, G., Rosen, B. R. (eds.) Biology and systematics of colonial organisms. Academic Press, London, p. 499-555

Jackson, J. B. C., Palumbi, S. R. (1979). Regeneration and partial predation in cryptic coral reef environments: preliminary experiments on sponges and ectoprocts. In: Lévi C., Boury-Esnault, N. (eds.) Biologie des spongiaires, Vol 291. Coll. Int. du C.N.R.S., Paris, p. 303-308

Korotkova, G. P. (1963). On the types of restoration processes in sponges. Acta Biol. Hung. 13: 389-406

La Barre, S. C., Coll, J. C. Sammarco, P. W. (1986). Defensive strategies of soft corals (Coelenterata: Octocorallia) of the Great Barrier Reef. II. The relationship between toxicity and feeding deterrence. Biol. Bull. mar biol. Lab., Woods Hole 171: 565-576

Lang da Silveira, F., van 't Hof, T. (1977). Regeneration in Plexaura flexuosa. Bijdr Dierk. 47: 98-108

Palumbi, S. R., Jackson, J. B. C. (1982). Ecology of cryptic coral reef communities. II. Recovery from small disturbance events by encrusting bryozoa: the influence of 'host' species and lesion size. J. exp. mar. Biol. Ecol. 64: 103-115

Pawlik, J. R. (1983). A sponge-eating worm from Bermuda: Branchiosyllis oculata (polychaeta, Syllidae). P.S.Z.N.I Mar. Ecol. 4: 65-79

Randall, J. E., Hartman, W. D. (1968). Sponge-feeding fishes of the West Indies. Mar Biol. 1. 216-225

Reiswig, H. M. (1973). Population dynamics of three jamaican Demospongiae. Bull. mar Sci. 23: 191-226

Sarà, M., Vacelet, J (1973). Ecologie des Démosponges. In Grassé, P. P. (ed.) Traité de zoologie, Vol. 3. Masson et Cie Paris, p. $462-576$

Storr, J. F. (1964). Ecology of the gulf of Mexico commercial sponges and its relation to the fishery. Spec. Sci. Rept Fish. 466. U.S. Fish and Wildlife Service, Washingon, p. 73

Storr, J. F. (1976). Field observations of sponge reactions as related to their ecology. In: Harrison, F. W., Cowden, R (eds.) Aspects of sponge biology. Academic Press, London, p. $277-282$

Wahle, C. M. (1983). Regeneration of injuries among Jamaican gorgonians: the roles of colony physiology and environment Biol. Bull. mar. biol. Lab., Woods Hole 165: 778-790 